\title{
REMOVAL OF THE CALIFORNIUM SOURCES FROM THE 222-S LABORATORY
}

Prepared by: Donna Linstrum, Energy Solutions Federal Services, Inc.

Prepared for: Washington River Protection Solutions, LLC

Richland, WA 99352

U.S. Department of Energy Contract DE-AC27-08RV14800

$\begin{array}{lll}\text { EDT/ECN: } & \text { EDT }-823210 & \text { UC: } \\ \text { Cost Center: } & & \text { Charge Code: } \\ \text { B\&R Code: } & & \text { Total Pages: } 37\end{array}$

Key Words: Californium; 222-S; Removal; Laboratory; Cf-252.

Abstract: This document develops a proposal for removal of two Californium sources from the 222-S Laboratory. Included in this document are assessments of shipping packages and decay calculations.

TRADEMARK DISCLAIMER. Reference herein to any specific commercial product, process, or service by trade name, trademark, manufacturer, or otherwise, does not necessarly constitute or imply its endorsement, recommendation, or favoring by the United States Government or any agency thereof or its contractors or subcontractors.

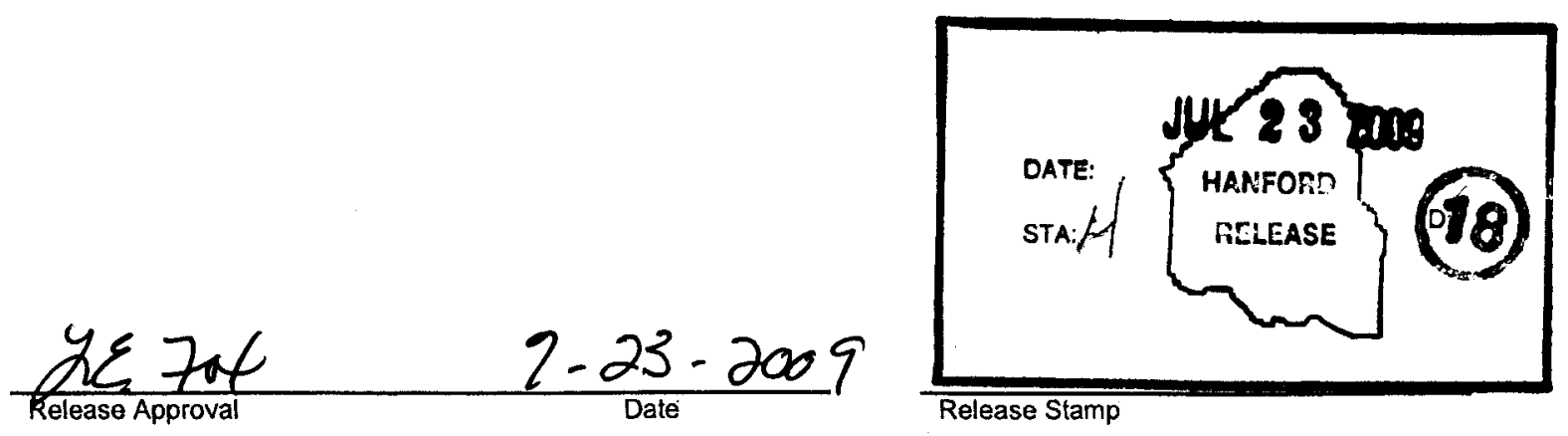

Approved For Public Release 
RPP-CALC-41849

Rev. 0

FSWO-RPT-095

Revision 0

\section{REMOVAL OF CALIFORNIUM SOURCES FROM THE 222-S LABORATORY}

June 2009

Prepared by:

EnergySolutions Federal Services, Inc., Northwest Operations

Richland, Washington

Prepared for:

Washington River Protection Solutions, LLC

Richland, Washington

Under Contract/Release 36473-45

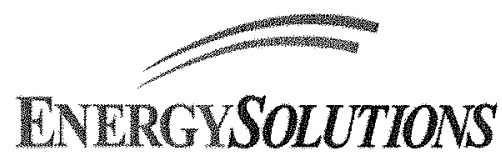


Rev. 0

\section{LIST OF ACRONYMS}

$\begin{array}{ll}\text { CFR } & \text { Code of Federal Regulations } \\ \text { DOE } & \text { U.S. Department of Energy } \\ \text { DOT } & \text { U.S. Department of Transportation } \\ \text { EM } & \text { Office of Environmental Management } \\ \text { EnergySolutions } & \text { EnergySolutions Federal Services, Inc. } \\ \text { IAEA } & \text { International Atomic Energy Agency } \\ \text { NAC } & \text { Nuclear Assurance Corporation } \\ \text { NMCA } & \text { Nuclear Material Control and Accounting } \\ \text { NRC } & \text { U.S. Nuclear Regulatory Commission } \\ \text { ORNL } & \text { Oak Ridge National Laboratory } \\ \text { RAMPAC } & \text { radioactive materials packaging database } \\ \text { SARP } & \text { Safety Analysis Report for Packaging } \\ \text { SP } & \text { special permit } \\ \text { WRPS } & \text { Washington River Protection Solutions, LLC }\end{array}$




\section{TABLE OF CONTENTS}

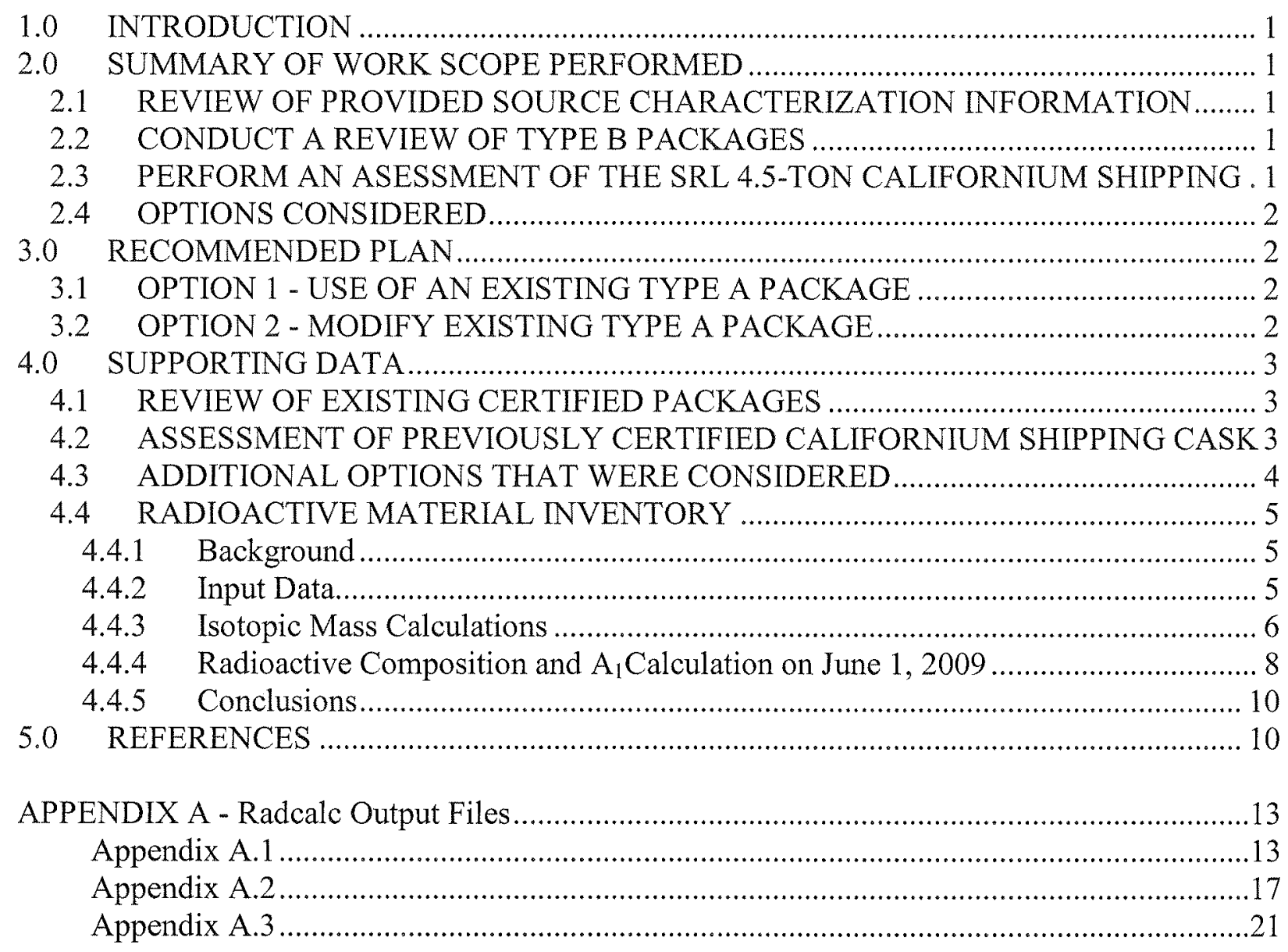

\section{LIST OF TABLES}

Table 1. Isotopic composition (as determined on January 13, 1999) and assumed nuclear parameters for source SR-CF-3052-OR

Table 2. Isotopic composition (as determined on August 10,2000) and assumed nuclear

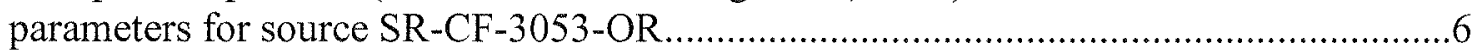

Table 3. Initial Isotopic composition for SR-CF-3052-OR on January 13, 1999 ….......................7

Table 4. Initial Isotopic composition for SR-CF-3053-OR on August 10, 2000 ….......................8

Table 5. Composition for SR-CF-3052-OR on June 1, 2009 from Radcalc..................................8

Table 6. Composition for SR-CF-3053-OR on June 1, 2009 from Radcalc ..................................9

Table 7. Composition for SR-CF-3053-OR on February 1, 2010 from Radcalc............................10 
FSWO-RPT-095, Rev. 0

RPP-CALC-41849

Rev. 0

This page intentionally left blank. 


\section{REMOVAL OF CALIFORNIUM SOURCES FROM THE 222-S LABORATORY}

\subsection{INTRODUCTION}

Washington River Protection Solutions, LLC (WRPS) has requested subcontracted support by EnergySolutions Federal Services, Inc., Northwest Operations (EnergySolutions) to develop a proposal for the removal of two Californium sources from the 222-S Laboratory that is located on the Hanford Site in Richland, Washington. The scope of work for this task is described in the WRPS Statement of Work, Request for Offsite Services Number 36473-45.

\subsection{SUMMARY OF WORK SCOPE PERFORMED}

\subsection{REVIEW OF PROVIDED SOURCE CHARACTERIZATION INFORMATION}

The Californium source information provided to EnergySolutions by WRPS was analyzed with the Radcalc 4.1 computer code (FSWO 2009) to establish the shipping requirements. As further discussed in Section 4.4 of this document, one of the Californium sources has decayed to a Type A quantity of radioactive material, and the other source will have decayed to a Type A quantity after February 2010. Therefore, after February 2010, both Californium sources can be shipped in a Type A package.

\subsection{CONDUCT A REVIEW OF TYPE B PACKAGES}

As discussed in Section 4.1, there are currently no Type B packages that are certified to ship the Californium sources.

\subsection{PERFORM AN ASESSMENT OF THE SRL 4.5-TON CALIFORNIUM SHIPPING CASK}

As discussed in Section 4.2, the SRL 4.5-ton Californium shipping cask can no longer be used to ship Type B quantities of radioactive material. However, the cask could be used to ship the sources after February 2010 when both sources have decayed to a Type A quantity of radioactive material. Also, Oak Ridge National Laboratory (ORNL) has other Type A packages that could be used to ship these identified sources. 


\title{
2.4 OPTIONS CONSIDERED
}

Several options were considered and are discussed in Section 4.3. The two most promising options are discussed in Section 3.0.

\subsection{RECOMMENDED PLAN}

\subsection{OPTION 1 - USE OF AN EXISTING TYPE A PACKAGE}

As noted in Section 4.4, after February 2010 both Californium sources will be decayed to a Type A quantity of radioactive material. This could allow the SRL 4.5-ton Californium shipping cask to be used for shipping the sources to ORNL. The use, availability, and cost of the cask will need to be coordinated with ORNL. This option should be the most cost and schedule effective option as the cask is designed to ship these sources. Initial discussions with the ORNL staff identified below indicate that there are several Type A packages available for shipping the Californium sources. In addition, ORNL staff conveyed that there is an authorization process that must be followed when transferring or returning the Californium sources.

If the ORNL packages are available (yet to be confirmed), the estimated lease costs are less than $\$ 10,000$ per month, and the estimated transportation costs are $\$ 6,000$ each one way trip between the Hanford Site and the ORNL. Additional information will be provided when contact is made with ORNL.

\section{ORNL Contacts:}

\author{
Julie Ezold \\ Cf Source Program Manager \\ 865-574-9594 \\ Darren MalKemus \\ Cf Source Loan Program \\ 865-574-0437 \\ Paulette McGill \\ Nuclear Material Control and Accounting (NMCA) \\ 865-574-7022
}

\subsection{OPTION 2 - MODIFY EXISTING TYPE A PACKAGE}

A second viable option is to modify an existing Type A package for shipment of the sources after February 2010. EnergySolutions owns several Type A packages that are of the size required to 
house the sources and associated shielding material. This option would require the design, analysis, and fabrication of an internal container that would be placed inside the selected Type A package. The design, analysis, and fabrication costs are estimated to be between $\$ 100,000$ to $\$ 200,000$ and require six to nine months to complete. The Type A package lease costs are estimated to be $\$ 6,000$ per month, and transportation costs are estimated to be $\$ 6,000$ each, oneway trip.

\subsection{SUPPORTING DATA}

\subsection{REVIEW OF EXISTING CERTIFIED PACKAGES}

A search was conducted using the U.S. Department of Energy (DOE), Office of Environmental Management's (EM) radioactive materials packaging (RAMPAC) online database (located at http://www.rampac.energy.gov) for any certified Type B packages for shipping sealed sources containing ${ }^{252} \mathrm{Cf}$. This query did not return any currently certified U.S. Nuclear Regulatory Commission (NRC) or DOE packages. The query returned 35 Competent Authority Certifications for Californium sealed sources, and only one package as having a DOE certification for shipping ${ }^{252} \mathrm{Cf}$ within a special form sealed source. This package is identified as the SRL 4.5-Ton Cf, USA/6642/B( ) (DOE), and the certification expired effective October 1, 2008.

In addition, the DOE/EM, Packaging Certification Program published the catalog, DOE Certified Radioactive Materials Transportation Packagings (DOE 2008). This catalog identifies several Type B, DOE-certified packages. The catalog lists 11 currently certified DOE packages authorized for specified payloads, none of which include ${ }^{252} \mathrm{Cf}$ or which would be suitable for transporting the special form sealed sources requested under a Safety Analysis Reports for Packaging (SARP) payload modification. Two packages, the ORNL TRU Cf (USA/5740/B() (DOE), and the SRL 4.5-Ton Cf (USA/6642/B( ) (DOE) were listed as authorized prior to October 2008 for shipment of Cf special form radioactive material under their specified SARPs.

The RAMPAC website was also checked for any listings of special permits (SP) with DOE as the holder for ${ }^{252} \mathrm{Cf}$ special form sealed sources, and none were found.

\subsection{ASSESSMENT OF PREVIOUSLY CERTIFIED CALIFORNIUM SHIPPING CASK}

The SRL 4.5-ton Californium shipping cask was originally used to ship the Californium sources to the Hanford Site in the year 2000. The Certificate of Compliance, USA/6642/B( ) (DOE), for the cask expired in October 2008, and the cask is no longer authorized to ship Type B quantities of radioactive material. Recertification of the cask as a Type $B$ package is considered to be impractical due to the age of the cask and changes in regulatory requirements. However, the 
cask could be certified to ship Type A quantities of radioactive material and could be used to ship the two Californium sources after February 2010.

\subsection{ADDITIONAL OPTIONS THAT WERE CONSIDERED}

The following additional options were considered:

1. Recertify the expired SRL 4.5-ton Californium shipping cask.

Recertification of the SRL 4.5-ton Californium shipping cask as a Type B package would require a new SARP that would include a detailed justification for why this package would meet current licensing requirements. It is estimated that the preparation of a new SARP could cost from $\$ 500,000$ to $\$ 1,000,000$ and the entire recertification effort could exceed three years. Due to the age of this package, the likelihood of obtaining approval is considered to be low. Therefore, this option is not considered feasible. Also, if the shipment were scheduled after February 2010, a Type B package would no longer be required.

2. Obtain a U.S. Department of Transportation (DOT) SP to use the expired SRL 4.5-ton Californium shipping cask.

Obtaining an SP to use the SRL 4.5-ton Californium cask could take six to nine months and would not be required after February 2010, which is approximately eight months away. Also, the chance of getting an SP is considered to be low since the package certification expired $1 \frac{1}{2}$ years ago.

3. Use the Nuclear Assurance Corporation (NAC) Californium Transport System.

NAC has been working with ORNL to develop and certify a Type B package for the transport of Californium sources. The cask has been under development since 1996; however, recent information from ORNL indicates that development of the package is no longer being funded and certification will not occur within the next few years.

4. Build a new Type B package.

Building a new Type B package would be both cost and schedule prohibitive. This is similar to what NAC was doing (see Item 3, above) and was not successful. Also, if shipping is to be done after February 2010, a Type B package would no longer be required.

5. Search for an International Atomic Energy Agency (IAEA) package.

A search for a suitable IAEA package could be undertaken. However, even if a suitable package could be found, the package would be required to undergo a review by DOT and the review could be as costly as a new package review, which is estimated to cost between $\$ 500,000$ and $\$ 1,000,000$ and require three to five years of time. Therefore, this option is not considered to be feasible. 


\subsection{RADIOACTIVE MATERIAL INVENTORY}

\subsubsection{Background}

In 2000, the 222-S laboratory received the two ${ }^{252} \mathrm{Cf}$ neutron sources from ORNL as identified below. These sources are certified as special form per IAEA Certificate of Competent Authority, Special Form Radioactive Materials, Certificate Number USA/0236/S, Rev. 2 (DOT 1996).

- SR-CF-3052-OR, which was assayed at ORNL on June 6, 2000 to obtain a calculated ${ }^{252} \mathrm{Cf}$ mass of $44,059.6 \mu \mathrm{g} \pm 0.21 \%$.

- SR-CF-3053-OR, which was assayed at ORNL on August 29, 2000 to obtain a calculated ${ }^{252} \mathrm{Cf}$ mass of $58,683.3 \mu \mathrm{g} \pm .25 \%$.

The calculations provided as Appendix A to this document use the initial assay and ${ }^{252} \mathrm{Cf}$ mass to determine the radioactive material inventory and the number of $\mathrm{A}_{1} \mathrm{~s}$ for each source on June 1, 2009. The provided information will support shipment of these sources back to ORNL.

\subsubsection{Input Data}

The input data for the calculations provided in Appendix A of this document is taken from the ORNL information sheets for SR-CF-3052-OR and SR-CF-3053-OR. This information was obtained from Attachments 1 and 2 (respectively) of the WRPS-provided document, Corrected Activity Estimates for Cf-252 Sources SR-CF-3052-OR and SR-CF-3053-OR [RPP-CALC-37588, Rev. 0 (dated July 31, 2008)] (Hanni 2008).

Sections 4.4.2.1 and 4.4.2.2 contain a summary of the ORNL input data that is used in the Appendix A information. Additional nuclear data for the daughter nuclides is given in Section 4.4.4. Conclusions of this evaluation are presented in Section 4.4.5.

\subsubsection{SR-CF-3052-OR Input Data}

Table 1 contains the isotopic composition for source SR-CF-3052-OR along with other nuclear data for these isotopes. The relevant dates for this source are January 13, 1999 when the isotopic mass distribution was measured, and June 6, 2000 when the neutron emission rate was measured to determine the mass of the ${ }^{252} \mathrm{Cf}$ component. The measured neutron emission rate was $1.0209 \cdot 10^{11} \mathrm{n} / \mathrm{s} \pm 0.21 \%$ for this source. The total estimated uncertainty is $\pm 3 \%$. Table 1 also includes the $\mathrm{A}_{1}$ values from Title 10, Part 71 of the Code of Federal Regulations (CFR), "Packaging and Transportation of Radioactive Material," Appendix A, "Determination of A1 and A2." 
Table 1. Isotopic composition (as determined on January 13, 1999) and assumed nuclear parameters for source SR-CF-3052-OR.

\begin{tabular}{|c|c|c|c|c|}
\hline Nuclide & $\begin{array}{c}\text { Atom \% } \\
(1 / 13 / 1999)\end{array}$ & $\begin{array}{c}\text { Half-Life } \\
\text { years }\end{array}$ & $\begin{array}{c}\text { Atomic } \\
\text { Mass }^{\mathrm{a}}\end{array}$ & $\begin{array}{c}\mathrm{A}_{1}{ }^{\mathrm{b}} \\
\mathrm{Bq}\end{array}$ \\
\hline${ }^{249} \mathrm{Cf}$ & 4.32 & 351.0 & 249.07485 & $3.0 \mathrm{E}+12$ \\
\hline${ }^{250} \mathrm{Cf}$ & 10.82 & 13.08 & 250.07641 & $2.0 \mathrm{E}+13$ \\
\hline${ }^{251} \mathrm{Cf}$ & 3.31 & 897.9 & 251.07959 & $7.0 \mathrm{E}+12$ \\
\hline${ }^{252} \mathrm{Cf}$ & 81.50 & 2.645 & 252.08163 & $1.0 \mathrm{E}+11$ \\
\hline${ }^{253} \mathrm{Cf}$ & 0.04 & 0.049 & 253.08513 & $4.0 \mathrm{E}+13$ \\
\hline${ }^{254} \mathrm{Cf}$ & 0.01 & 0.166 & 254.08732 & $1.0 \mathrm{E}+09$ \\
\hline
\end{tabular}

${ }^{\mathrm{a}}$ From FSWO 2009.

${ }^{\mathrm{b}}$ From 10 CFR 71, Appendix A.

\subsubsection{SR-CF-3053-OR Input Data}

Table 2 contains the isotopic composition for source SR-CF-3053-OR along with other nuclear data for these isotopes. The relevant dates for this source are August 10,2000 when the isotopic mass distribution was measured, and August 29, 2000 when the neutron emission rate was measured to determine the mass of the ${ }^{252} \mathrm{Cf}$ component. The measured neutron emission rate for this source was $1.3594 \cdot 10^{11} \mathrm{n} / \mathrm{s} \pm 0.25 \%$. The overall estimated uncertainty is $\pm 3 \%$. Table 2 also includes the $A_{1}$ values from 10 CFR 71, Appendix A.

Table 2. Isotopic composition (as determined on August 10, 2000) and assumed nuclear parameters for source SR-CF-3053-OR.

\begin{tabular}{|c|c|c|c|c|}
\hline Nuclide & $\begin{array}{c}\text { Atom } \% \\
(8 / 10 / 2000)\end{array}$ & $\begin{array}{c}\text { Half-Life } \\
\text { Years }\end{array}$ & $\begin{array}{c}\text { Atomic } \\
\text { Mass }^{\mathrm{a}}\end{array}$ & $\begin{array}{c}\mathrm{A}_{1}{ }^{\mathrm{b}} \\
\mathrm{Bq}\end{array}$ \\
\hline${ }^{249} \mathrm{Cf}$ & 7.15 & 351.0 & 249.07485 & $3.0 \mathrm{E}+12$ \\
\hline${ }^{250} \mathrm{Cf}$ & 14.69 & 13.08 & 250.07641 & $2.0 \mathrm{E}+13$ \\
\hline${ }^{251} \mathrm{Cf}$ & 5.05 & 897.9 & 251.07959 & $7.0 \mathrm{E}+12$ \\
\hline${ }^{252} \mathrm{Cf}$ & 73.10 & 2.645 & 252.08163 & $1.0 \mathrm{E}+11$ \\
\hline${ }^{253} \mathrm{Cf}$ & $\leq 0.01$ & 0.049 & 253.08513 & $4.0 \mathrm{E}+13$ \\
\hline${ }^{254} \mathrm{Cf}$ & $\leq 0.01$ & 0.166 & 254.08732 & $1.0 \mathrm{E}+09$ \\
\hline
\end{tabular}

${ }^{\mathrm{a}}$ From FSWO 2009.

${ }^{b}$ From 10 CFR 71, Appendix A.

\subsubsection{Isotopic Mass Calculations}

\subsubsection{SR-CF-3052-OR - Initial Mass Composition on January 13, 1999}

The initial isotopic masses are evaluated in this section. Table 3 shows the derivation of the initial isotopic masses for the other Californium isotopes based on the calculated ${ }^{252} \mathrm{Cf}$ mass of $44,059.6 \mu \mathrm{g}$ on June 6,2000 . Because the isotopic composition for this source was measured on January 13,1999 , the ${ }^{252} \mathrm{Cf}$ mass of $44,059.6 \mu \mathrm{g}$ on June 6,2000 will be back-decayed to 
establish the initial ${ }^{252} \mathrm{Cf}$ mass on January 13, 1999. The back-decay correction factor for 1.40 years (January 13, 1999 to June 6, 2000) is:

$$
\text { Correction Factor }=\mathrm{N}_{0} / \mathrm{N}=\exp \left(\ln (2)^{*} 1.40 \mathrm{y} / 2.645 \mathrm{y}\right)=1.4433
$$

The initial ${ }^{252} \mathrm{Cf}$ mass corrected to January 13,1999 is $63,591 \mu \mathrm{g}(=44,059.6 \mu \mathrm{g} \mathrm{x} \mathrm{1.4433).} \mathrm{The}$ remaining Californium isotope masses are calculated as shown in Table 3.

Table 3. Initial Isotopic composition for SR-CF-3052-OR on January 13, 1999.

\begin{tabular}{|c|c|c|c|c|c|}
\hline Nuclide & $\begin{array}{c}\text { Atom \% } \\
(1 / 13 / 1999)\end{array}$ & $\begin{array}{c}\text { Atomic } \\
\text { Mass }^{\mathrm{a}}\end{array}$ & $\begin{array}{c}\text { Atom \% x } \\
\text { Atomic Mass }\end{array}$ & $\begin{array}{c}\text { Mass } \\
\text { Fraction }^{\mathrm{b}}\end{array}$ & $\begin{array}{c}\text { Mass } \\
\text { grams }^{\mathrm{c}}\end{array}$ \\
\hline${ }^{249} \mathrm{Cf}$ & 4.32 & 249.07485 & 1076.003 & 0.042749 & 0.003331 \\
\hline${ }^{250} \mathrm{Cf}$ & 10.82 & 250.07641 & 2705.827 & 0.107501 & 0.008375 \\
\hline${ }^{251} \mathrm{Cf}$ & 3.31 & 251.07959 & 831.0734 & 0.033018 & 0.002572 \\
\hline${ }^{252} \mathrm{Cf}$ & 81.50 & 252.08163 & 20544.65 & 0.816229 & $0.063591^{\mathrm{d}}$ \\
\hline${ }^{253} \mathrm{Cf}$ & 0.04 & 253.08513 & 10.12341 & 0.000402 & 0.000031 \\
\hline${ }^{254} \mathrm{Cf}$ & 0.01 & 254.08732 & 2.540873 & 0.000101 & 0.000008 \\
\hline Total & 100.00 & & 25170.22 & 1.000000 & 0.077909 \\
\hline
\end{tabular}

${ }^{\mathrm{a}}$ From FSWO 2009.

${ }^{\mathrm{b}}$ Mass fraction $=$

(Atom \% x Atomic Mass of isotope)/(Total Atom \% x Atomic Mass for all isotopes).

${ }^{c}$ Mass $=$ Mass ${ }^{252} \mathrm{Cf} \times$ (Mass fraction of isotope) $/\left(\right.$ Mass fraction of ${ }^{252} \mathrm{Cf}$ ).

${ }^{d}$ Mass of ${ }^{252} \mathrm{Cf}=0.063591$ grams when back-decayed to January 13,1999 .

\subsubsection{SR-CF-3053-OR - Initial Mass Composition on August 10, 2000}

The initial and decayed isotopic masses are evaluated in this section. Table 4 shows the derivation of the initial isotopic masses for the other Californium isotopes based on the calculated ${ }^{252} \mathrm{Cf}$ mass of 58,683.3 $\mu \mathrm{g}$ on August 29, 2000. Because the isotopic composition for this source was measured on August 10, 2000, the ${ }^{252} \mathrm{Cf}$ mass of $58,683.3 \mu \mathrm{g}$ will be back-decayed to establish the initial ${ }^{252} \mathrm{Cf}$ mass on $8 / 10 / 2000$. The back-decay correction factor for 0.052 years (August 10, 2000 to August 29, 2000) is:

$$
\text { Correction Factor }=\mathrm{N}_{0} / \mathrm{N}=\exp \left(\ln (2)^{*} 0.052 \mathrm{y} / 2.645 \mathrm{y}\right)=1.0137
$$

The initial ${ }^{252} \mathrm{Cf}$ mass corrected to August 10,2000 is $59,487 \mu \mathrm{g}(=58,683.3 \mu \mathrm{g} \times 1.0137)$. The remaining Californium isotope masses are calculated as shown in Table 4. 
Table 4. Initial Isotopic composition for SR-CF-3053-OR on August 10, 2000.

\begin{tabular}{|c|c|c|c|c|c|}
\hline Nuclide & $\begin{array}{c}\text { Atom \% } \\
(8 / 10 / 2000)\end{array}$ & $\begin{array}{c}\text { Atomic } \\
\text { Mass }^{\mathrm{a}}\end{array}$ & $\begin{array}{c}\text { Atom \% x } \\
\text { Atomic Mass }\end{array}$ & $\begin{array}{c}\text { Mass } \\
\text { Fraction }^{\mathrm{b}}\end{array}$ & $\begin{array}{c}\text { Mass } \\
\text { grams }^{\mathrm{c}}\end{array}$ \\
\hline${ }^{249} \mathrm{Cf}$ & 7.15 & 249.07485 & 1780.885 & 0.070797 & 0.005607 \\
\hline${ }^{250} \mathrm{Cf}$ & 14.69 & 250.07641 & 3673.622 & 0.146041 & 0.011565 \\
\hline${ }^{251} \mathrm{Cf}$ & 5.05 & 251.07959 & 1267.952 & 0.050406 & 0.003992 \\
\hline${ }^{252} \mathrm{Cf}$ & 73.10 & 252.08163 & 18427.17 & 0.732554 & $0.059487^{\mathrm{d}}$ \\
\hline${ }^{253} \mathrm{Cf}$ & $\leq 0.01^{\mathrm{e}}$ & 253.08513 & 2.530851 & 0.000101 & 0.000008 \\
\hline${ }^{254} \mathrm{Cf}$ & $\leq 0.01^{\mathrm{e}}$ & 254.08732 & 2.540873 & 0.000101 & 0.000008 \\
\hline Total & 100.01 & & 25154.7 & 1.000000 & 0.080667 \\
\hline
\end{tabular}

${ }^{\mathrm{a}}$ From FSWO 2009.

${ }^{\mathrm{b}}$ Mass fraction $=$

(Atom \% x Atomic Mass of isotope)/(Total Atom \% x Atomic Mass for all isotopes).

${ }^{\mathrm{c}}$ Mass $=$ Mass ${ }^{252} \mathrm{Cf} \times$ (Mass fraction of isotope)/(Mass fraction of ${ }^{252} \mathrm{Cf}$ ).

${ }^{\mathrm{d}}$ Mass of ${ }^{252} \mathrm{Cf}=0.059487$ grams when back-decayed to August 10, 2000.

${ }^{\mathrm{e}}$ Conservatively set to 0.01 atom $\%$.

\subsubsection{Radioactive Composition and $A_{1}$ Calculation on June 1, 2009}

\subsubsection{SR-CF-3052-OR - Radioactive Composition and $A_{1}$ Calculation on June 1, 2009}

The initial mass of the Californium isotopes from Table 3 were entered into Radcalc and decayed to June 1,2009. The resulting mass and activity composition at June 1, 2009 is shown in Table 5 along with the $A_{1}$ calculation. There are dozens of daughter products resulting from the decay of the Californium isotopes. Table 5 only lists those isotopes with greater than $1 \mathrm{E}-5 \mathrm{Ci}(3.7 \mathrm{E} 5 \mathrm{~Bq})$ on June 1, 2009. There is less than $1 \mathrm{~A}_{1}\left(0.832 \mathrm{~A}_{1}\right)$ at a decay date of June 1,2009 ; therefore, this source is designated as a Type A quantity.

Table 5. Composition for SR-CF-3052-OR on June 1, 2009 from Radcalc ${ }^{\mathrm{a}}$.

\begin{tabular}{|c|c|c|c|c|c|}
\hline Nuclide & $\begin{array}{c}\text { Activity } \\
\mathrm{Ci}\end{array}$ & $\begin{array}{c}\text { Activity } \\
\text { Bq }\end{array}$ & $\begin{array}{c}\text { Mass } \\
\text { grams }\end{array}$ & $\begin{array}{c}\mathrm{A}_{1}{ }^{\mathrm{b}} \\
\mathrm{Bq}\end{array}$ & $\begin{array}{c}\text { No. of } \\
\mathbf{A}_{\mathbf{1}} \mathbf{s}\end{array}$ \\
\hline $\mathrm{Cm}-245$ & $1.15 \mathrm{E}-05$ & $4.25 \mathrm{E}+05$ & $6.70 \mathrm{E}-05$ & $9.0 \mathrm{E}+12$ & $4.73 \mathrm{E}-08$ \\
\hline $\mathrm{Cm}-246$ & $1.07 \mathrm{E}-03$ & $3.96 \mathrm{E}+07$ & $3.48 \mathrm{E}-03$ & $9.0 \mathrm{E}+12$ & $4.40 \mathrm{E}-06$ \\
\hline $\mathrm{Cm}-248$ & $2.40 \mathrm{E}-04$ & $8.88 \mathrm{E}+06$ & $5.67 \mathrm{E}-02$ & $2.0 \mathrm{E}+10$ & $4.44 \mathrm{E}-04$ \\
\hline Bk-249 & $1.53 \mathrm{E}-05$ & $5.67 \mathrm{E}+05$ & $9.35 \mathrm{E}-09$ & $4.0 \mathrm{E}+13$ & $1.42 \mathrm{E}-08$ \\
\hline Cf-249 & $1.35 \mathrm{E}-02$ & $4.98 \mathrm{E}+08$ & $3.29 \mathrm{E}-03$ & $3.0 \mathrm{E}+12$ & $1.66 \mathrm{E}-04$ \\
\hline Cf-250 & $5.28 \mathrm{E}-01$ & $1.95 \mathrm{E}+10$ & $4.83 \mathrm{E}-03$ & $2.0 \mathrm{E}+13$ & $9.77 \mathrm{E}-04$ \\
\hline Cf-251 & $4.05 \mathrm{E}-03$ & $1.50 \mathrm{E}+08$ & $2.55 \mathrm{E}-03$ & $7.0 \mathrm{E}+12$ & $2.14 \mathrm{E}-05$ \\
\hline Cf-252 & $2.24 \mathrm{E}+00$ & $8.30 \mathrm{E}+10$ & $4.19 \mathrm{E}-03$ & $1.0 \mathrm{E}+11$ & $8.30 \mathrm{E}-01$ \\
\hline Totals & $2.79 \mathrm{E}+00$ & $1.03 \mathrm{E}+11$ & $7.51 \mathrm{E}-02$ & & $\mathbf{8 . 3 2 E - 0 1}$ \\
\hline
\end{tabular}

${ }^{a}$ Only those isotopes with an activity greater than $1 \mathrm{E}-5 \mathrm{Ci}$ are shown.

${ }^{b}$ From 10 CFR 71, Appendix A. 
The Radcalc output file for this calculation is provided as Appendix A.1. To perform transportation calculations, Radcalc requires a container mass, waste mass, and waste volume to be entered by the user. Arbitrary values were used as input for these parameters since the only transportation quantity of interest was the number of $A_{1} \mathrm{~S}$, and this calculation is unaffected by those parameters.

\subsubsection{SR-CF-3053-OR - Radioactive Composition and $A_{1}$ Calculations on June 1, 2009 and February 1, 2010}

The initial mass of the Californium isotopes from Table 4 were entered into Radcalc and decayed to June 1,2009. The resulting mass and activity composition at June 1, 2009 is shown in Table 6 along with the $\mathrm{A}_{1}$ calculation. There are dozens of daughter products resulting from the decay of the Californium isotopes. Table 6 only lists those isotopes with greater than $1 \mathrm{E}-5 \mathrm{Ci}(3.7 \mathrm{E} 5 \mathrm{~Bq})$ on June 1, 2009. There is slightly greater than $1 \mathrm{~A}_{1}\left(1.18 \mathrm{~A}_{1}\right)$ at a decay date of June 1, 2009; therefore, this source is designated as a Type $\mathrm{B}$ quantity for this decay time.

Table 6. Composition for SR-CF-3053-OR on June 1, 2009 from Radcalc ${ }^{\mathrm{a}}$.

\begin{tabular}{|c|c|c|c|c|c|}
\hline Nuclide & $\begin{array}{c}\text { Activity } \\
\mathrm{Ci}\end{array}$ & $\begin{array}{c}\text { Activity } \\
\mathrm{Bq}\end{array}$ & $\begin{array}{c}\text { Mass } \\
\text { grams }\end{array}$ & $\begin{array}{c}\mathrm{A}_{1}{ }^{\mathrm{b}} \\
\mathrm{Bq}\end{array}$ & $\begin{array}{c}\text { No. of } \\
\mathbf{A}_{\mathbf{1}} \mathbf{s}\end{array}$ \\
\hline $\mathrm{Cm}-245$ & $1.63 \mathrm{E}-05$ & $6.05 \mathrm{E}+05$ & $9.52 \mathrm{E}-05$ & $9.0 \mathrm{E}+12$ & $6.72 \mathrm{E}-08$ \\
\hline $\mathrm{Cm}-246$ & $1.30 \mathrm{E}-03$ & $4.82 \mathrm{E}+07$ & $4.24 \mathrm{E}-03$ & $9.0 \mathrm{E}+12$ & $5.35 \mathrm{E}-06$ \\
\hline $\mathrm{Cm}-248$ & $2.17 \mathrm{E}-04$ & $8.01 \mathrm{E}+06$ & $5.11 \mathrm{E}-02$ & $2.0 \mathrm{E}+10$ & $4.01 \mathrm{E}-04$ \\
\hline Bk-249 & $1.37 \mathrm{E}-05$ & $5.08 \mathrm{E}+05$ & $8.38 \mathrm{E}-09$ & $4.0 \mathrm{E}+13$ & $1.27 \mathrm{E}-08$ \\
\hline Cf-249 & $2.26 \mathrm{E}-02$ & $8.35 \mathrm{E}+08$ & $5.52 \mathrm{E}-03$ & $3.0 \mathrm{E}+12$ & $2.78 \mathrm{E}-04$ \\
\hline Cf-250 & $7.93 \mathrm{E}-01$ & $2.93 \mathrm{E}+10$ & $7.25 \mathrm{E}-03$ & $2.0 \mathrm{E}+13$ & $1.47 \mathrm{E}-03$ \\
\hline Cf-251 & $6.29 \mathrm{E}-03$ & $2.33 \mathrm{E}+08$ & $3.96 \mathrm{E}-03$ & $7.0 \mathrm{E}+12$ & $3.32 \mathrm{E}-05$ \\
\hline Cf-252 & $3.17 \mathrm{E}+00$ & $1.17 \mathrm{E}+11$ & $5.92 \mathrm{E}-03$ & $1.0 \mathrm{E}+11$ & $1.17 \mathrm{E}+00$ \\
\hline Totals & $3.99 \mathrm{E}+00$ & $1.48 \mathrm{E}+11$ & $7.81 \mathrm{E}-02$ & & $1.18 \mathrm{E}+\mathbf{0 0}$ \\
\hline
\end{tabular}

${ }^{a}$ Only those isotopes with an activity greater than $1 \mathrm{E}-5 \mathrm{Ci}$ are shown.

${ }^{b}$ From 10 CFR 71, Appendix A.

The Radcalc output file for this calculation is provided as Appendix A.2. To perform transportation calculations, Radcalc requires a container mass, waste mass, and waste volume to be entered by the user. Arbitrary values were used as input for these parameters since the only transportation quantity of interest was the number of $\mathrm{A}_{1} \mathrm{~S}$, and this calculation is unaffected by those parameters.

Table 7 shows the composition at a decay date of February 1, 2010. At this decay time there is less than $1 \mathrm{~A}_{1}\left(0.987 \mathrm{~A}_{1}\right)$ which means that it may be shipped in a Type A package after February 1, 2010. 
Table 7. Composition for SR-CF-3053-OR on February 1, 2010 from Radcalc ${ }^{\mathrm{a}}$.

\begin{tabular}{|c|c|c|c|c|c|}
\hline Nuclide & $\begin{array}{c}\text { Activity } \\
\mathrm{Ci}\end{array}$ & $\begin{array}{c}\text { Activity } \\
\mathrm{Bq}\end{array}$ & $\begin{array}{c}\text { Mass } \\
\text { grams }\end{array}$ & $\begin{array}{c}\mathrm{A}_{1}^{\mathrm{b}} \\
\mathrm{Bq}\end{array}$ & $\begin{array}{c}\text { No. of } \\
\mathbf{A}_{1} \mathbf{s}\end{array}$ \\
\hline $\mathrm{Cm}-245$ & $1.76 \mathrm{E}-05$ & $6.50 \mathrm{E}+05$ & $1.02 \mathrm{E}-04$ & $9.0 \mathrm{E}+12$ & $7.22 \mathrm{E}-08$ \\
\hline $\mathrm{Cm}-246$ & $1.38 \mathrm{E}-03$ & $5.10 \mathrm{E}+07$ & $4.49 \mathrm{E}-03$ & $9.0 \mathrm{E}+12$ & $5.67 \mathrm{E}-06$ \\
\hline $\mathrm{Cm}-248$ & $2.20 \mathrm{E}-04$ & $8.15 \mathrm{E}+06$ & $5.20 \mathrm{E}-02$ & $2.0 \mathrm{E}+10$ & $4.08 \mathrm{E}-04$ \\
\hline $\mathrm{Cf}-249$ & $2.25 \mathrm{E}-02$ & $8.34 \mathrm{E}+08$ & $5.51 \mathrm{E}-03$ & $3.0 \mathrm{E}+12$ & $2.78 \mathrm{E}-04$ \\
\hline $\mathrm{Cf}-250$ & $7.65 \mathrm{E}-01$ & $2.83 \mathrm{E}+10$ & $7.00 \mathrm{E}-03$ & $2.0 \mathrm{E}+13$ & $1.42 \mathrm{E}-03$ \\
\hline Cf-251 & $6.28 \mathrm{E}-03$ & $2.32 \mathrm{E}+08$ & $3.96 \mathrm{E}-03$ & $7.0 \mathrm{E}+12$ & $3.32 \mathrm{E}-05$ \\
\hline Cf-252 & $2.66 \mathrm{E}+00$ & $9.84 \mathrm{E}+10$ & $4.96 \mathrm{E}-03$ & $1.0 \mathrm{E}+11$ & $9.84 \mathrm{E}-01$ \\
\hline Totals & $3.46 \mathrm{E}+00$ & $1.28 \mathrm{E}+11$ & $7.80 \mathrm{E}-02$ & & $\mathbf{9 . 8 7 E - 0 1}$ \\
\hline
\end{tabular}

${ }^{\mathrm{a}}$ Only those isotopes with an activity greater than $1 \mathrm{E}-5 \mathrm{Ci}$ are shown.

${ }^{b}$ From 10 CFR 71, Appendix A.

The Radcalc output file for this calculation is provided as Appendix A.3. To perform transportation calculations, Radcalc requires a container mass, waste mass, and waste volume to be entered by the user. Arbitrary values were used as input for these parameters since the only transportation quantity of interest was the number of $\mathrm{A}_{1} \mathrm{~s}$, and this calculation is unaffected by those parameters.

\subsubsection{Conclusions}

Tables 5 and 6 list the radioactive material inventory on June 1, 2009, for sources SR-CF-3052-OR and SR-CF-3053-OR, respectively. Source SR-CF-3052-OR contains less than $1 \mathrm{~A}_{1}$ on June 1, 2009 and may be shipped in a Type A package. Source SR-CF-3053-OR contains slightly greater than $1 \mathrm{~A}_{1}$ on June 1, 2009; however, if this source is shipped after February 1,2010, it may be shipped in a Type A package because it will contain less than $1 \mathrm{~A}_{1}$ on February 1, 2010. The radioactive material inventory for source SR-CF-3053-OR on February 1, 2010 is listed in Table 7.

\subsection{REFERENCES}

10 CFR 71, "Packaging and Transportation of Radioactive Material," Code of Federal Regulations, as amended.

DOE, 2008, DOE Certified Radioactive Materials Transportation Packages, U.S. Department of Energy, Office of Environmental Management, Washington, D.C. 
DOT, 1996, IAEA Certificate of Competent Authority, Special Form Radioactive Materials, Certificate Number USA/0236/S, Rev. 2, U. S. Department of Transportation, Research and Special Programs Administration, Washington, D.C.

FSWO, 2009, Radcalc 4.1 User's Manual, FSWO-SQA-026, Rev. 0, EnergySolutions Federal Services, Inc., Northwest Operations, Richland, Washington.

Hanni, Jonathan B., 2008, Corrected Activity Estimates for Cf-252 Sources SR-CF-3052-OR and $S R-C F-3053-O R$ [RPP-CALC-37588, Rev. 0, dated July 31, 2008], Richland, Washington. 
FSWO-RPT-095, Rev. 0

RPP-CALC-41849

Rev. 0

This page intentionally left blank. 


\section{APPENDIX A - Radcalc Output Files}

\section{A.1 - SR-CF-3052-OR on June 1, 2009}

Radcalc 4.1: C:IProgram FileslEnergySolutionsIRadcalc 4.1lcf source 3052 at 6-1-2009.rad
Performed By: A. V. Savinol
Checked By: J. A. Dewberry'

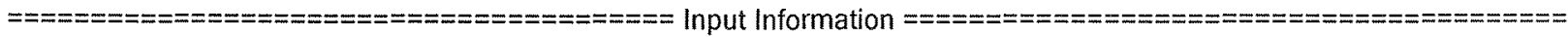

Comments:

Initial Source Data:

$\begin{array}{llll}\text { Isotope } & \mathrm{Ci} & \mathrm{Gm} & \mathrm{TBq} \\ \text { Cf-249 } & 1.362 \mathrm{E}-02 & 3.331 \mathrm{E}-03 & 5.040 \mathrm{E}-04 \\ \mathrm{Cf}-250 & 9.153 \mathrm{E}-01 & 8.375 \mathrm{E}-03 & 3.387 \mathrm{E}-02 \\ \mathrm{Cf}-251 & 4.078 \mathrm{E}-03 & 2.572 \mathrm{E}-03 & 1.509 \mathrm{E}-04 \\ \mathrm{Cf}-252 & 3.410 \mathrm{E}+01 & 6.359 \mathrm{E}-02 & 1.262 \mathrm{E}+00 \\ \text { Cf-253 } & 8.980 \mathrm{E}-01 & 3.100 \mathrm{E}-05 & 3.323 \mathrm{E}-02 \\ \text { Cf-254 } & 6.795 \mathrm{E}-02 & 8.000 \mathrm{E}-06 & 2.514 \mathrm{E}-03 \\ & & & \overline{1.332 \mathrm{E}+00}\end{array}$

* Radionuclides with an activity of less than $1 \mathrm{E}-05 \mathrm{Ci}$ will not be shown in the output.

* Radionuclides with an A1/A2 fraction of less than 0.001 will not be shown in the output.

Container Data:

Container Void Volume: $\quad 0 \quad \mathrm{~m}^{\wedge} 3$

Container Mass:

Mass of solid beryllium, lead, graphite, and hydrogenous material enriched with deuterium:

Gross Mass:

$\begin{array}{ll}0 & \mathrm{~m}^{\wedge} 3 \\ 1 & \mathrm{~kg} \\ 0 & \mathrm{~kg} \\ 2 & \mathrm{~kg}\end{array}$

Waste Data:

Waste Form:

Waste State:

Waste Volume:

Waste Mass:

Mass of solid lead:

Mass of solid beryllium, graphite, and hydrogenous material enriched with deuterium:

Waste Void Volume:

$\begin{array}{ll}\text { Special } & \\ \text { Solid } & \\ 1 & \mathrm{~m}^{\wedge} 3 \\ 1 & \mathrm{~kg} \\ 0 & \mathrm{~kg} \\ 0 & \mathrm{~kg} \\ 0 & \mathrm{~m}^{\wedge} 3\end{array}$

Decay Time Data:

Date to begin source decay: $\quad 1 / 13 / 1999$

Date container sealed: $\quad 6 / 1 / 2009$

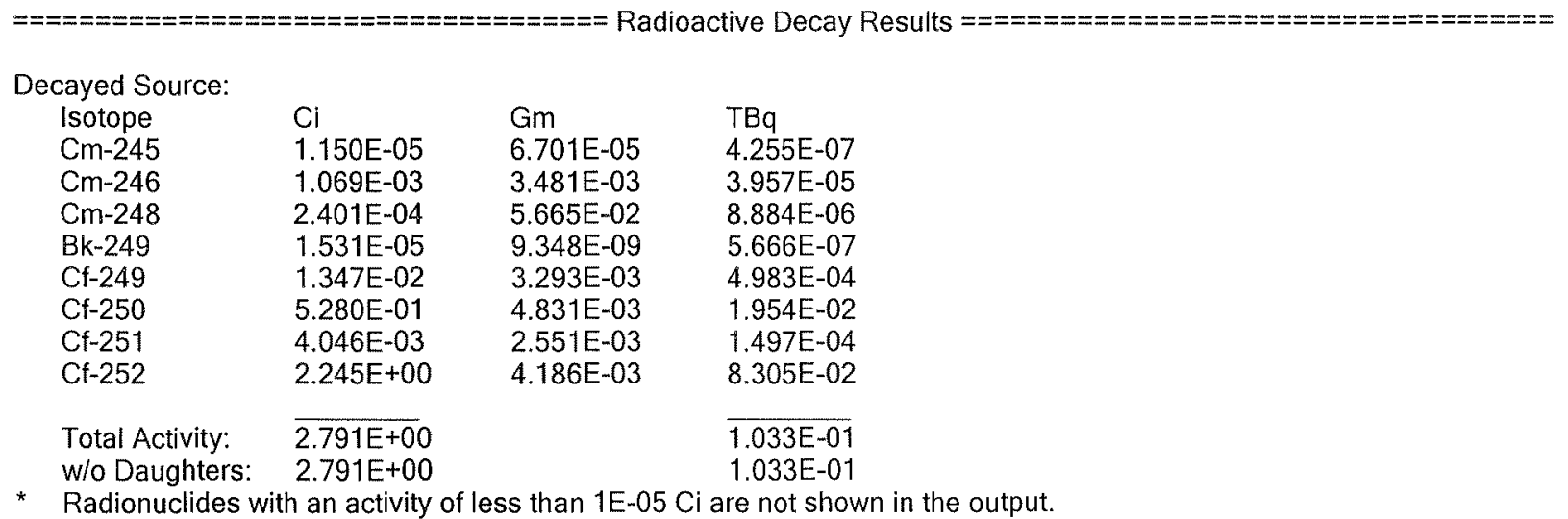


Decay Heat:

Heat Generated on Start Date: $\quad 2.466 \quad$ W

Heat Generated on Seal Date: 0.1804 W

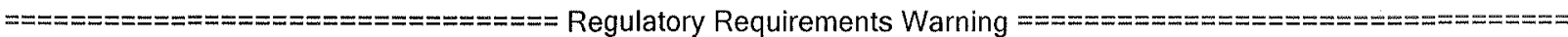

Radcalc utilizes numerically based criteria to classify packages against the regulations. Many regulations also include subjective criteria that Radcalc does not consider. The user must check to ensure that all requirements in the regulations are met.

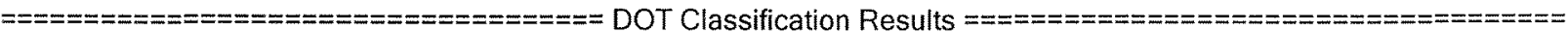

* DOT classification calculations are made at the end of the user-specified decay time.

Radioactive Determination:

$\begin{array}{llll}\text { Radioactive: } & \text { Yes } & & \text { (ACEMs and ALECs > 1.0) } \\ \text { ACEM Limit Fraction: } & 10960000 & \text { ACEMs } & \text { (Number of ACEMs) } \\ \text { ALEC Limit Fraction: } & 10960000 & \text { ALECS } & \text { (Number of ALECs) }\end{array}$

* This package is not exempt from 49 CFR Subchapter C.

Effective A1s for Mixture: $\quad 1.241 \mathrm{E}+11 \quad \mathrm{~Bq}$

Type Determination:

Type:

A

$($ A1s $<=1.0)$

A1 Limit Fraction:

0.8321

A1s

(Number of A1s)

* For shipment outside the US, evaluate this package against the 49 CFR 173.435 international limits for Cf-252.

Limited Quantity Determination:

Limited Quantity: No

Activity:

Fissile:

Fissile Excepted:

0.8321

2.791

0.1033

Yes

Yes (a)

LSA Determination:

LSA-I:

LSA-II:

LSA-III:

Specific Activity:

HRCQ Determination:

HRCQ:

A1 Limit Fraction:

Activity:

Fissile Determination:

Fissile:

No

No

No

0.0008321

0.002791

No

0.8321

2.791

0.1033

Yes

Yes (a)

$2382 \mathrm{~F}-08$

Fissile Excepted:

Fissile Mass:

Container beryllium, lead, graphite, and hydrogenous material enriched with deuterium:

Container Mass:

Waste lead:

Waste beryllium, graphite, and hydrogenous material enriched with deuterium:

Waste Mass:

Solid Non-Fissile Mass:

Total Uranium Mass:

$\begin{array}{ll}0 & \mathrm{gm} \\ 1000 & \mathrm{gm} \\ 0 & \mathrm{gm} \\ & \\ 0 & \mathrm{gm} \\ 1000 & \mathrm{gm} \\ 0 & \mathrm{gm} \\ 1.875 \mathrm{E}-11 & \mathrm{gm}\end{array}$

$\mathrm{A} 1 / \mathrm{gm}$

$\mathrm{Ci} / \mathrm{gm}$

A1s

$\mathrm{Ci}$

$\mathrm{TBq}$

A1

$\mathrm{Ci}$

$\mathrm{TBq}$

(Solid, activity $>0.001 \mathrm{~A} 1$ )

(Fissile excepted, ACEMs $>30 \times$ rad limits)

(Special form)

(Special form)

$($ A2s $<=3000$, Activity $<=1000 \mathrm{TBq})$

(Contains fissile isotopes per 49 CFR 173.403)

(Fissile isotopes $<=2$ grams) 


$\begin{array}{lll}\text { U-233 Mass: } & 1.117 \mathrm{E}-17 & \mathrm{gm} \\ \text { U-235 Mass: } & 1.048 \mathrm{E}-19 & \mathrm{gm} \\ \text { Uranium Enrichment: } & 5.591 \mathrm{E}-07 & \% \\ \text { Total Plutonium Mass: } & 3.628 \mathrm{E}-06 & \mathrm{gm} \\ \text { Pu-239 Mass: } & 1.43 \mathrm{E}-15 & \mathrm{gm} \\ \text { Pu-241 Mass: } & 2.382 \mathrm{E}-08 & \mathrm{gm}\end{array}$

Reportable Quantity Determination:

Reportable Quantity: $\quad$ Yes

$\mathrm{RQ}$ Limit Fraction:

77.35

RQs

(RQs $>=1.0)$

(Number of RQs)

Shipping Papers and Labels:

$\begin{array}{lllll}\text { Isotope } & \text { Number of A1s } & \text { Fraction of A1s } & \text { Cumulative A1s } & \text { Cumulative Fraction of A1s } \\ \text { Cf-252 } & 0.8305 & 0.9981 & 0.8305 & 0.9981\end{array}$

Cf-250 $\quad 0.0009768$

+ Contains $95 \%$ of the total A1s and must be included per 49 CFR 173.433 .

* Radionuclides comprising less than $0.1 \%$ of the total A1s are not shown in the list.

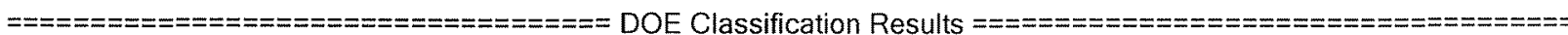

* DOE classification calculations are made at the end of the user-specified decay time.

DOE-STD-1027 Category Determination:

Category:

Cat 2 Limit Fraction:

Cat 3

0.02014

$($ Cat $3 s>1.0$, Cat $2 s<=1.0)$

Cat 3 Limit Fraction:

1.247

* The DOE-STD-1027 category determination is based on dose-related limits.

The user must apply any criticality-related limits separately.

Dose-Equivalent Curies: ICRP-72 DE-Ci: $\quad 1.283$

FGR-11 DE-Ci: $\quad 1.168$

TRU Waste Determination:

$\begin{array}{llll}\text { TRU Waste: } & \text { Yes } & & \text { (TRU activity }>100 \mathrm{nCi} / \mathrm{gm} \text { ) } \\ \text { TRU Activity: } & 18830 & \mathrm{nCi} / \mathrm{g} & \end{array}$

WIPP Quantities:

FGE Value:

0.3788

PE-Ci Value:

0.826

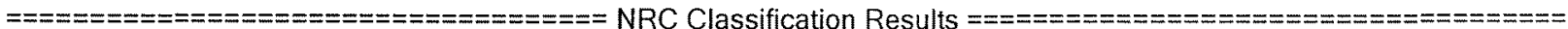

* NRC classification calculations are made at the end of the user-specified decay time.

NRC Container Category:

Container Category:

LSA-I:

III

LSA-II:

LSA-III:

Total Activity:

No

A1 Limit Fraction:

No

$2.791 \quad \mathrm{Ci}$

$0.8321 \quad$ A1s 
FSWO-RPT-095, Rev. 0

RPP-CALC-41849

Rev. 0

This page intentionally left blank. 
Radcalc 4.1: C:IProgram FileslEnergySolutionsiRadcalc 4.1/cf source 3053 at 6-1-2009.rad

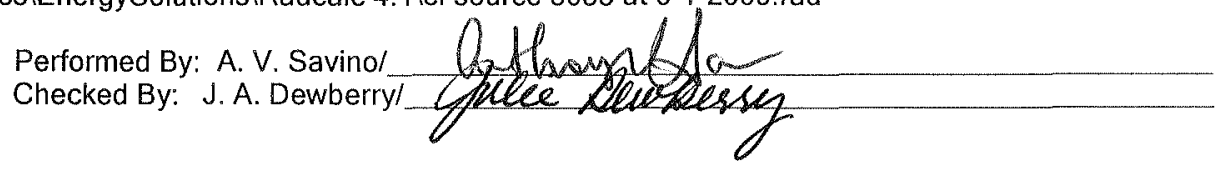

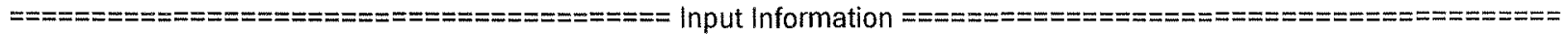

Comments:

Initial Source Data:

$\begin{array}{llll}\text { Isotope } & \mathrm{Ci} & \mathrm{Gm} & \mathrm{TBq} \\ \mathrm{Cf}-249 & 2.293 \mathrm{E}-02 & 5.607 \mathrm{E}-03 & 8.483 \mathrm{E}-04 \\ \mathrm{Cf}-250 & 1.264 \mathrm{E}+00 & 1.157 \mathrm{E}-02 & 4.677 \mathrm{E}-02 \\ \mathrm{Cf}-251 & 6.330 \mathrm{E}-03 & 3.992 \mathrm{E}-03 & 2.342 \mathrm{E}-04 \\ \mathrm{Cf}-252 & 3.190 \mathrm{E}+01 & 5.949 \mathrm{E}-02 & 1.180 \mathrm{E}+00 \\ \mathrm{Cf}-253 & 2.318 \mathrm{E}-01 & 8.000 \mathrm{E}-06 & 8.575 \mathrm{E}-03 \\ \mathrm{Cf}-254 & 6.795 \mathrm{E}-02 & 8.000 \mathrm{E}-06 & 2.514 \mathrm{E}-03 \\ & & & \\ \text { Total Activity: } & \overline{3.349 \mathrm{E}+01} & & \overline{1.239 \mathrm{E}+00}\end{array}$

* Radionuclides with an activity of less than $1 \mathrm{E}-05 \mathrm{Ci}$ will not be shown in the output.

* Radionuclides with an A1/A2 fraction of less than 0.001 will not be shown in the output.

Container Data:

Container Void Volume: $\quad 0 \quad \mathrm{~m}^{\wedge} 3$

Container Mass:

Mass of solid beryllium, lead, graphite, and hydrogenous material enriched with deuterium:

Gross Mass:

$\begin{array}{ll}1 & \mathrm{~kg} \\ 0 & \mathrm{~kg} \\ 2 & \mathrm{~kg}\end{array}$

Waste Data:

Waste Form: Special

Waste State: Solid

Waste Volume:

Waste Mass:

Mass of solid lead:

Mass of solid beryllium, graphite, and hydrogenous material enriched with deuterium:

Waste Void Volume:

$\begin{array}{ll}\text { Solid } & \mathrm{m}^{\wedge} 3 \\ 1 & \mathrm{~kg} \\ 1 & \mathrm{~kg} \\ 0 & \\ & \mathrm{~kg} \\ 0 & \mathrm{~m}^{\wedge} 3\end{array}$

Decay Time Data:

Date to begin source decay: $\quad 8 / 10 / 2000$

Date container sealed: $\quad 6 / 1 / 2009$

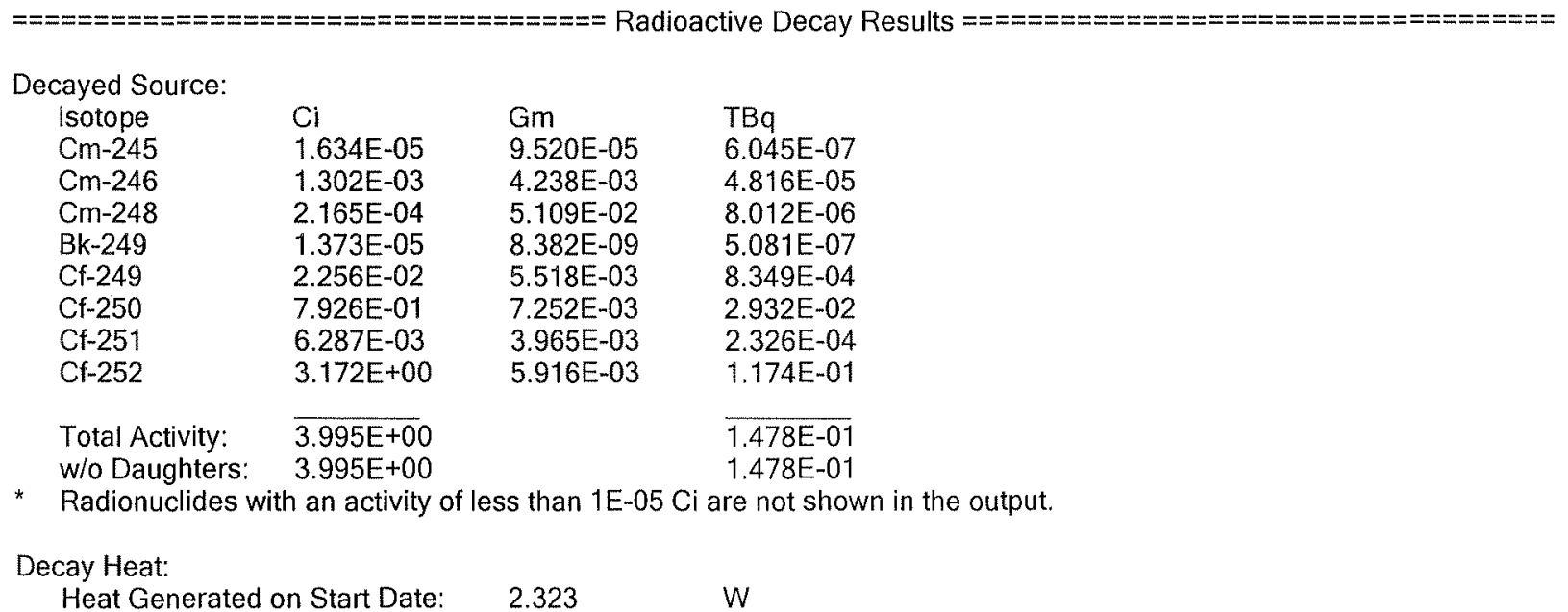


Radcalc utilizes numerically based criteria to classify packages against the regulations. Many regulations also include subjective criteria that Radcalc does not consider. The user must check to ensure that all requirements in the regulations are met.

* DOT classification calculations are made at the end of the user-specified decay time.

Radioactive Determination:

$\begin{array}{llll}\text { Radioactive: } & \text { Yes } & & \text { (ACEMs and ALECs }>1.0 \text { ) } \\ \text { ACEM Limit Fraction: } & 15790000 & \text { ACEMs } & \text { (Number of ACEMs) } \\ \text { ALEC Limit Fraction: } & 15790000 & \text { ALECS } & \text { (Number of ALECs) }\end{array}$

* This package is not exempt from 49 CFR Subchapter C.

Effective A1s for Mixture: $\quad 1.257 \mathrm{E}+11 \quad \mathrm{~Bq}$

Type Determination:
Type:
B 1.176
$($ A1s $>1.0)$
A1 Limit Fraction:
1.176
A1s (Number of A1s)

* For shipment outside the US, evaluate this package against the 49 CFR 173.435 international limits for Cf-252.

Limited Quantity Determination: Limited Quantity:

Activity:

Fissile:

Fissile Excepted:

No

1.176

3.995

0.1478

Yes

Yes (a)

LSA Determination:

LSA-I:

LSA-II:

LSA-III:

Specific Activity:

HRCQ Determination:

HRCQ:

A1 Limit Fraction:

Activity:

Fissile Determination:

Fissile:

No

No

No

0.001176

0.003995

No

1.176

3.995

0.1478

Yes

Yes (a)

2.94E-08

gm

0

1000

0

Waste lead:

Waste beryllium, graphite, and hydrogenous material enriched with deuterium:

Waste Mass:

Solid Non-Fissile Mass:

Total Uranium Mass:

U-233 Mass:

U-235 Mass:

Uranium Enrichment:
0

1000

0

1.612E-11

8.271E-18

$8.425 \mathrm{E}-20$

$5.226 \mathrm{E}-07$ gm

$\mathrm{gm}$

$\mathrm{gm}$

$\mathrm{gm}$

$\mathrm{gm}$

$\mathrm{gm}$

$\mathrm{gm}$

$\mathrm{gm}$

gm
A1/gm

$\mathrm{Ci} / \mathrm{gm}$

A1s

$\mathrm{Ci}$

$\mathrm{TBq}$

A1

$\mathrm{Ci}$

(Solid, activity $>0.001$ A1)

(Fissile excepted, ACEMs $>30 \times$ rad limits) (Special form)

(Special form)

$($ A2s $<=3000$, Activity $<=1000 \mathrm{TBq})$

(Contains fissile isotopes per 49 CFR 173.403)

(Fissile isotopes $<=2$ grams) 
Total Plutonium Mass:

Pu-239 Mass:

Pu-241 Mass:

$\begin{array}{ll}3.489 E-06 & \mathrm{gm} \\ 1.355 \mathrm{E}-15 & \mathrm{gm} \\ 2.94 \mathrm{E}-08 & \mathrm{gm}\end{array}$

Rev. 0

Reportable Quantity Determination:

Reportable Quantity:

$\mathrm{RQ}$ Limit Fraction:

$\begin{array}{lll}\text { Yes } & & (\text { RQs }>=1.0) \\ 114.2 & \text { RQs } & \text { (Number of RQs) }\end{array}$

Shipping Papers and Labels:
Isotope
Cf-252
Number of A1s
1.174
Fraction of A1s
0.9981
Cumulative A1s
1.174
Cumulative Fraction of A1s

Cf-250

0.001466

0.001247

1.175

+ Contains $95 \%$ of the total A1s and must be included per 49 CFR 173.433 .

* Radionuclides comprising less than $0.1 \%$ of the total A1s are not shown in the list.

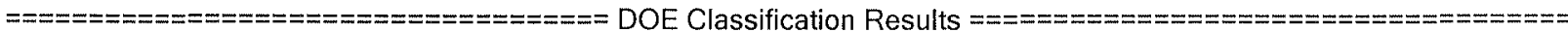

* DOE classification calculations are made at the end of the user-specified decay time.

DOE-STD-1027 Category Determination:

Category:

Cat 2 Limit Fraction:

Cat 3

0.02938

$($ Cat $3 \mathrm{~s}>1.0$, Cat $2 \mathrm{~s}<=1.0)$

Cat 3 Limit Fraction:

1.813

* The DOE-STD-1027 category determination is based on dose-related limits.

The user must apply any criticality-related limits separately.

Dose-Equivalent Curies:

ICRP-72 DE-Ci: $\quad 1.85$

FGR-11 DE-Ci: $\quad 1.684$

TRU Waste Determination:

TRU Waste:

TRU Activity:

Yes

30390

$\mathrm{nCi} / \mathrm{g}$

(TRU activity $>100 \mathrm{nCi} / \mathrm{gm}$ )

WIPP Quantities:

FGE Value:

0.6066

PE-Ci Value:

1.191

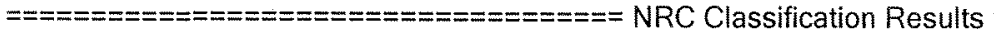

* NRC classification calculations are made at the end of the user-specified decay time.

NRC Container Category:

Container Category:

LSA-I:

LSA-II:

LSA-III:

Total Activity:

A1 Limit Fraction:

III

No

No

No

1.176
$\mathrm{Ci}$

A1s 
FSWO-RPT-095, Rev. 0

RPP-CALC-41849

Rev. 0

This page intentionally left blank. 


\section{A.3 - SR-CF-3053-OR on February 1, 2010}

Radcalc 4.1: $\quad$ C:IProgram FilesIEnergySolutions\Radcalc 4.1lcf source 3053 at 2-1-2010.rad

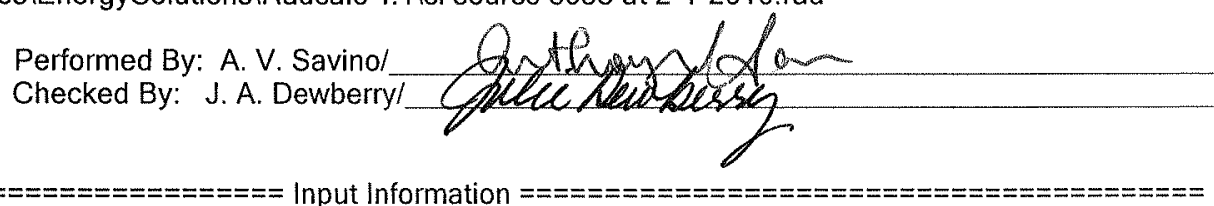

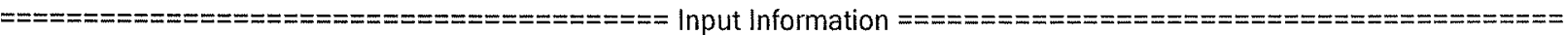

Comments:

Initial Source Data:

$\begin{array}{llll}\text { Isotope } & \mathrm{Ci} & \mathrm{Gm} & \mathrm{TBq} \\ \text { Cf-249 } & 2.293 \mathrm{E}-02 & 5.607 \mathrm{E}-03 & 8.483 \mathrm{E}-04 \\ \text { Cf-250 } & 1.264 \mathrm{E}+00 & 1.157 \mathrm{E}-02 & 4.677 \mathrm{E}-02 \\ \text { Cf-251 } & 6.330 \mathrm{E}-03 & 3.992 \mathrm{E}-03 & 2.342 \mathrm{E}-04 \\ \text { Cf-252 } & 3.190 \mathrm{E}+01 & 5.949 \mathrm{E}-02 & 1.180 \mathrm{E}+00 \\ \text { Cf-253 } & 2.318 \mathrm{E}-01 & 8.000 \mathrm{E}-06 & 8.575 \mathrm{E}-03 \\ \text { Cf-254 } & 6.795 \mathrm{E}-02 & 8.000 \mathrm{E}-06 & 2.514 \mathrm{E}-03\end{array}$

Total Activity: $\quad \overline{3.349 E+01} \overline{1.239 E+00}$

* Radionuclides with an activity of less than $1 \mathrm{E}-05 \mathrm{Ci}$ will not be shown in the output.

* Radionuclides with an A1/A2 fraction of less than 0.001 will not be shown in the output.

Container Data:

Container Void Volume: $\quad 0 \quad \mathrm{~m}^{\wedge} 3$

Container Mass:

Mass of solid beryllium, lead, graphite, and hydrogenous material enriched with deuterium:

Gross Mass:

$1 \quad \mathrm{~kg}$

Waste Data:

Waste Form: Special

Waste State:

Waste Volume:

Waste Mass:

Mass of solid lead:

Mass of solid beryllium, graphite, and hydrogenous material enriched with deuterium:

Waste Void Volume:

$\begin{array}{ll}\text { Solid } & \\ 1 & \mathrm{~m}^{\wedge} 3 \\ 1 & \mathrm{~kg} \\ 0 & \mathrm{~kg} \\ & \\ 0 & \mathrm{~kg} \\ 0 & \mathrm{~m}^{\wedge} 3\end{array}$

Decay Time Data:

Date to begin source decay: $\quad 8 / 10 / 2000$

Date container sealed: $\quad 2 / 1 / 2010$

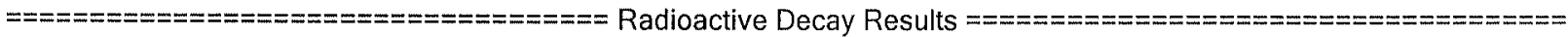

Decayed Source:

$\begin{array}{llll}\text { Isotope } & \mathrm{Ci} & \mathrm{Gm} & \mathrm{TBq} \\ \mathrm{Cm}-245 & 1.757 \mathrm{E}-05 & 1.024 \mathrm{E}-04 & 6.501 \mathrm{E}-07 \\ \mathrm{Cm}-246 & 1.378 \mathrm{E}-03 & 4.486 \mathrm{E}-03 & 5.099 \mathrm{E}-05 \\ \mathrm{Cm}-248 & 2.204 \mathrm{E}-04 & 5.200 \mathrm{E}-02 & 8.155 \mathrm{E}-06 \\ \mathrm{Cf}-249 & 2.253 \mathrm{E}-02 & 5.511 \mathrm{E}-03 & 8.338 \mathrm{E}-04 \\ \mathrm{Cf}-250 & 7.649 \mathrm{E}-01 & 6.998 \mathrm{E}-03 & 2.830 \mathrm{E}-02 \\ \mathrm{Cf}-251 & 6.283 \mathrm{E}-03 & 3.963 \mathrm{E}-03 & 2.325 \mathrm{E}-04 \\ \text { Cf-252 } & 2.661 \mathrm{E}+00 & 4.962 \mathrm{E}-03 & 9.844 \mathrm{E}-02 \\ & & & \\ \text { Total Activity: } & 3.456 \mathrm{E}+00 & & 1.279 \mathrm{E}-01 \\ \text { w/o Daughters: } & 3.456 \mathrm{E}+00 & & 1.279 \mathrm{E}-01\end{array}$

* Radionuclides with an activity of less than $1 \mathrm{E}-05 \mathrm{Ci}$ are not shown in the output.

Decay Heat:

Heat Generated on Start Date: $2.323 \quad$ W

Heat Generated on Seal Date: $\quad 0.2193 \quad$ W 


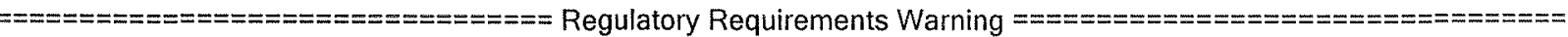

Radcalc utilizes numerically based criteria to classify packages against the regulations. Many regulations also include subjective criteria that Radcalc does not consider. The user must check to ensure that all requirements in the regulations are met.

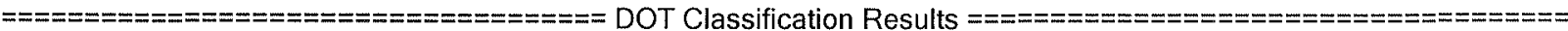

* DOT classification calculations are made at the end of the user-specified decay time.

Radioactive Determination:

Radioactive:

ACEM Limit Fraction:

ALEC Limit Fraction:

* This package is not exempt from 49 CFR Subchapter C.

Effective A1s for Mixture:

1.296E+11 $\quad \mathrm{Bq}$

Type Determination:

Type:

A

0.9866

A1 Limit Fraction:

* For shipment outside the US, evaluate this package against the 49 CFR 173.435 international limits for $\mathrm{Cf}-252$.

Limited Quantity Determination:

Limited Quantity: $\quad$ No

Activity:

0.9866

3.456

0.1279

Fissile:

Yes

Fissile Excepted:

Yes (a)

LSA Determination:

LSA-I:

LSA-II:

LSA-III:

Specific Activity:

No

No

No

0.0009866

0.003456

A1/gm

A1

$\mathrm{Ci}$

$\mathrm{TBq}$

HRCQ Determination:

HRCQ:

A1 Limit Fraction:

Activity:

No

0.9866

3.456

0.1279

A1s

$\mathrm{Ci}$

$\mathrm{TBq}$

Fissile Determination:

Fissile:

Fissile Excepted Determination:

Fissile Excepted:

Fissile Mass:

Container beryllium, lead, graphite, and hydrogenous material enriched with deuterium:

Container Mass:

Waste lead:

Waste beryllium, graphite, and hydrogenous material enriched with deuterium:

Waste Mass:

Solid Non-Fissile Mass:

Total Uranium Mass:

U-233 Mass:

U-235 Mass:

Uranium Enrichment:

Total Plutonium Mass:
Yes

Yes (a)

3.369E-08

$g m$

0

1000

0

$g m$

$g m$

$\mathrm{gm}$

0

1000

0

$1.993 \mathrm{E}-11$

1.191E-17

1.13E-19

$5.672 \mathrm{E}-07$

3.979E-06
(ACEMs and ALECs > 1.0)

Number of ACEMs)

(Number of ALECs)
(A1s $<=1.0)$
(Number of A1s)
the 49 CFR 173.435

(Solid, activity $>0.001 \mathrm{~A} 1$ )

$\mathrm{Ci} / \mathrm{gm}$

$(\mathrm{A} 2 \mathrm{~s}<=3000$, Activity $<=1000 \mathrm{TBq})$
(Fissile excepted, ACEMs $>30 \times$ rad limits)

Special form

(Special form)

(Contains fissile isotopes per 49 CFR 173.403)

(Fissile isotopes $<=2$ grams) 
Pu-239 Mass:

Pu-241 Mass:

Reportable Quantity Determination:

Reportable Quantity:

$\mathrm{RQ}$ Limit Fraction:

Shipping Papers and Labels:

$\begin{array}{lllll}\text { Isotope } & \text { Number of A1s } & \text { Fraction of A1s } & \text { Cumulative A1s } & \text { Cumulative Fraction of A1s } \\ \text { Cf-252 } & 0.9844 & 0.9978 & 0.9844 & 0.9978 \\ \text { Cf-250 } & 0.001415 & 0.001434 & 0.9858 & 0.9993\end{array}$

+ Contains $95 \%$ of the total A1s and must be included per 49 CFR 173.433 .

* Radionuclides comprising less than $0.1 \%$ of the total $A 1 s$ are not shown in the list.

\subsection{E-15 gm \\ 3.369E-08 gm}

Yes $\quad(\mathrm{RQs}>=1.0)$

106.3 RQs (Number of RQs)

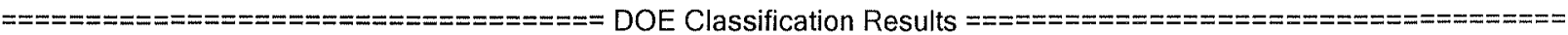

* DOE classification calculations are made at the end of the user-specified decay time.

DOE-STD-1027 Category Determination:

$\begin{array}{ll}\text { Category: } & \text { Cat } 3 \\ \text { Cat } 2 \text { Limit Fraction: } & 0.02655 \\ \text { Cat } 3 \text { Limit Fraction: } & 1.627\end{array}$

* The DOE-STD-1027 category determination is based on dose-related limits.

The user must apply any criticality-related limits separately.

Dose-Equivalent Curies:

ICRP-72 DE-Ci: $\quad 1.627$

FGR-11 DE-Ci: $\quad 1.481$

TRU Waste Determination:

TRU Waste: Yes

TRU Activity: $\quad 30430$

$\mathrm{nCi} / \mathrm{g}$

(TRU activity $>100 \mathrm{nCi} / \mathrm{gm}$ )

WIPP Quantities:

FGE Value: $\quad 0.6062$

PE-Ci Value: $\quad 1.048$

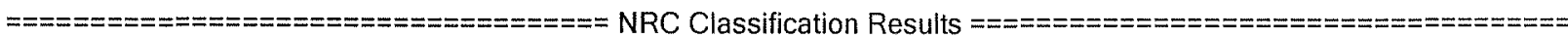

* NRC classification calculations are made at the end of the user-specified decay time.

NRC Container Category:

Container Category:

LSA-I:

LSA-II:

LSA-III:

Total Activity:

A1 Limit Fraction:

III

No

No

No

$3.456 \quad \mathrm{Ci}$

$0.9866 \quad$ A1s 
RPP-CALC-41849

Rev. 0

Subcontractor Calculation Review Checklist.

Page of

Subject: FSWO-RPT-095, Rev 0., Removal Of Californium Sources From The 222-S Laboratory

The subject document has been reviewed by the undersigned.

The reviewer reviewed and verified the following items as applicable.

Documents Reviewed: Subject document radioactive source decay calculations and quantities

Analysis Performed By: Energy Solutions Federal Services (Savino/Dewberry)

- Design Input

- Basic Assumptions $\checkmark$

- Approach/Design Methodology $\checkmark$

- Consistency with item or document supported by the calculation $\checkmark$

- Conclusion/Results Interpretation $\checkmark$

- Impact on existing requirements $\checkmark$

-

Reviewer (printed name, signature, and date)_Gary L Troyer 197 mav $6-\mathrm{JuL}-2009$ Organizational Manager (printed name, signature and date)_Greg L Parsons 42 Parsers 7-21-09 
From:

Sent:

To:

Cc:

Subject:

Attachments:
Donna Linstrum [djlinstrum@energysolutions.com]

Wednesday, July 22, 2009 1:19 PM

Baune, Heather L

Donna Linstrum

RE: Contract 36473-45 - Removal of Cf Sources from 222-S Lab (doc attached)

RC41_ESER_GOTS.pdf

Heather,

The information for the software code, version number, and user manual were noted within the documents provided. However, the additional, specific information requested within your message is provided below.

Program Name: Radcalc

Version: 4.1

Release Date: June 5, 2009 (see attached existing software evaluation report)

User Manual Reference: FSWO-SQA-026, Rev. 0. Also included as "User Help Files" as a part of the software code (i.e., drop-down menu)

Verification and Validation: FSWO-VV-029, Rev. 0, "Radcalc 4.1 Verification and Validation Test Report."

Radcalc was developed by EnergySolutions for use by the DOE and its subcontractors free of charge.

EnergySolutions has an NQA-1, 2000 Quality Assurance Program that also implements the requirements of DOE Order 414.1C regarding software. The "Software Management Procedure" used for development of this code is $Q P$ 3-10, Rev. 9.

Radcalc Version 4.1 is available for download at the following website for registered, approved users. All software quality assurance documentation (very extensive) is available in PDF format via that website by registered. approved users. hitps://www.radcalc.energy.gov

Regards,

\section{Donna Linstrum}

Energy Solutions, MSIN: G1-62

(Office) 509-375-9526

(Fax) 509-371-2457

djlinstrum@energysolutions.com

From: Baune, Heather L [mailto:Heather_L_Baune@RL.gov]

Sent: Wednesday, July 22, 2009 10:42 AM

To: Donna Linstrum

Subject: FW: Contract 36473-45 - Removal of Cf Sources from 222-S Lab (doc attached)

Donna,

Per our phone conversation, the following information is requested.

Documentation of computer codes shall include program name, version numbers, release dates, references to user manuals, and program verification data. If the calculation uses software that has 
l'd very much appreciate a quick turnaround on this information (in the next day or two) if at all possible.

Please contact me if you have questions.

Thank You,

Heather Baune

372-3393

From: Donna Linstrum [mailto:djlinstrum@energysolutions.com]

Sent: Wednesday, June 17, 2009 9:01 AM

To: Baune, Heather $L$

CC: Donna Linstrum; Lippert, Tracy D; Ferrell, Patrick C; Savino, Anthony V

Subject: Contract 36473-45 - Removal of Cf Sources from 222-S Lab (doc attached)

Heather,

The attached files are the released document. I will be sending you the original document via Plant Mail for records retention purposes.

If you have any question, please let me know.

Regards.

\section{Donna Linstrum}

Energy Solutions, MSIN: G1-62

(Office) 509-375-9526

(Fax) 509-371-2457

djlinstrum@energysolutions.com 


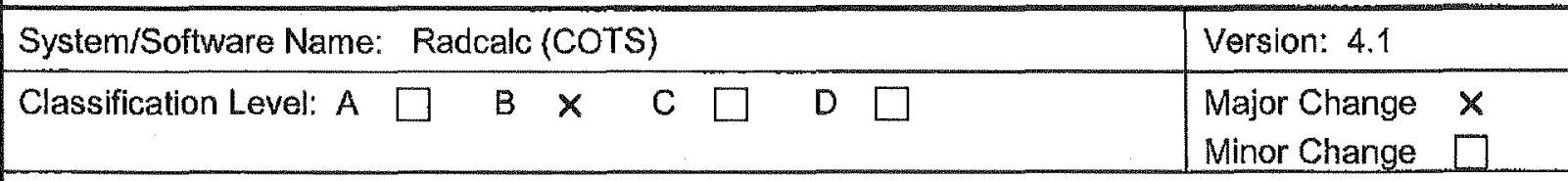

1. Describe purpose of software and software source.

Radcalc 4.1 corrects the documented errors, incorporates regulatory interpretations, and incorporates other enhancements identified since the release of Radcalc 4.0.

(Ref: EnergySolutions' PR/CRs-023 through -034, -059, and -061 as provided in FSWO-SQA-022, Rev, 1, Radcalc 4.1 Software Requirements Specification.)

Radcalc 4.1 capabilities include the following:

- Performs transportation classifications based on selected DOT definitions and methodologies identified in Title 49, Code of Federal Regulations, "Transportation."

- Performs calculations and classification functions using selected methodologies prescribed by the DOE, NRC, U.S. Environmental Protection Agency, and International Commission on Radiological Protection.

- Calculates the decay heat rate and activity of radionuclides and their daughter products at the end of a specified time interval.

- Calculates the radiolytic hydrogen gas generated in a radioactive waste matrix.

- Calculates the helium gas production from radioactive decay.

- Incorporates DOE-STD-1027, Change 1, Hazard Categorization and Accident Analysis Techniques for Compliance with DOE Order 5480.23, Nuclear Safety Analysis Reports, to classify packages using the Category 2 and Category 3 facility limits.

- Includes a complete set of DE-Ci values compiled from ICRP Publication 72, Age-dependent Doses to Members of the Public from Intake of Radionuclides: Part 5 Compilation of Ingestion and Inhalation Dose Coefficients, and FGR11/EPA-520/1-88-020, Limiting Values of Radionuclide Intake and Air Concentration and Dose Conversion Factors for Inhalation, Submersion, and Ingestion.

- Incorporates Revision 2 of the Contact-Handled Transuranic Waste Authorized Methods for Payload Control ( $\mathrm{CH}$-TRAMPAC) as the source of FGE values.

- Incorporates revisions to WIPP PE-Ci requirements current to Revision 6.2 of DOEMIPP-02-3122, Contact-Handled Transuranic Waste Acceptance Criteria for the Waste Isolation Pilot Plant. DOE/WIPP-02-3122 defines "TRU" differently than the more standard definition established in DOE Manual 435.1-1 Chg 1, Radioactive Waste Management Manual. This includes updating ${ }^{239} \mathrm{Pu}-$ equivalent curie (PE-Ci) database values for ${ }^{233} \mathrm{U}$ and ${ }^{237} \mathrm{~Np}$, and adding 60 other transuranic (TRU) isotopes to the calculation.

As identified within the software quality assurance documentation, Radcalc 4.1 requires a set of usersupplied input parameters to perform its calculations.

Radcalc 4.1 is a Secure Socket Layer (SSL), web-based software application that is available (free of charge) to registered/authorized users as defined and granted by the U.S. Department of Energy (DOE), Office of Packaging and Transportation (EM-63). Radcalc is distributed with database viewers 


\section{$\rightleftharpoons$ \\ ENERGYSOLUTIONS \\ EXISTING SOFTWARE EVALUATION REPORT}

\begin{tabular}{|l|l|}
\hline System/Software Name: Radcalc (COTS) & Version: 4.1 \\
\hline
\end{tabular}

that allow registered/authorized users to access the Radcalc nuclear, transportation classification and G-value database values on an isotope-by-isotope basis. Registered/authorized users may download the software and obtain all software quality assurance documentation from:

https://www.radcalc.energy,gov

2. Describe mathematical models and design basis.

The two documents identified below identify the mathematical models and design basis of Radcalc 4.1. The implementation document identifies the source code files for the software program.

- FSWO-SQA-023, 2009, Radcalc Software Design Description, Rev. 0, Energy Solutions Federal Services, Inc., Northwest Operations, Richland, Washington.

- FSWO-SQA-025, 2009, Radcalc Implementation Document, Rev. 0, EnergySolutions Federal Services, Inc., Northwest Operations, Richland, Washington.

3. Describe/List primitive baseline configuration items.

The relevant software quality assurance documents, as applicable to Radcalc 4.1 (dated March 26, 2009), are listed below. Registered/approved users have access to the listed documents via the Radcalc 4.1 website to these listed documents. These documents are available in PDF format.

- EnergySolutions, 2009, "Safety Software Quality Plan," Radcalc 4.1, EnergySolutions Federal Services, Inc., Northwest Operations, Richland, Washington, February 2009.

- FSWO-SQA-021, Rev. 0, Radcalc Version 4.1 Project Risk Evaluation Report, EnergySolutions Federal Services, Inc., Northwest Operations, Richland, Washington.

*See below for project specific RER

- FSWO-SQA-022, Rev. 1, Radcalc Software Requirements Specification (Current to Radcalc 4.1), EnergySolutions Federal Services, Inc., Northwest Operations, Richland, Washington.

- FSWO-SQA-023, Rev. 0, Radcaic Software Design Description (Current to Radcalc 4.1), EnergySolutions Federal Services, Inc., Northwest Operations, Richland, Washington.

- FSWO-SQA-025, Rev. 0, Radcalc 4.1 Implementation Document, EnergySolutions Federal Services, Inc., Northwest Operations, Richland, Washington.

- FSWO-SQA-026, Rev. 0, Radcalc 4.1 User Manual, EnergySolutions Federal Services, Inc., Northwest Operations, Richland, Washington. (Information is also included a drop-down menu within the software itself.)

- FSWO-V V-028, Rev. 0, Radcalc 4.1 Verification and Validation Plan and Test Procedure, EnergySolutions Federal Services, Inc., Northwest Operations, Richland, Washington.

- FSWO-V V-029, Rev. 0, Radcalc 4.1 Verification and Validation Test Report, EnergySolutions Federal Services, Inc., Northwest Operations, Richland, Washington.

- PR/CR's are tracked by the baseline software configuration control as identified in QP 3-10, Rev, 9, 


\begin{tabular}{|c|c|}
\hline ENERGYSOLUTTONS & EXISTING SOFTWARE EVALUATION REPORT \\
\hline System/Software Name: Radcalc (COTS) & Version: 4.1 \\
\hline $\begin{array}{l}\text { Software Management. } \\
\text { *Project-Specific Risk Evaluation Report } \\
\text { prepared unless contractually directed o } \\
\text { COTS/GOTS software that is classed as } \\
\text { Project Risk Management Evaluation for }\end{array}$ & $\begin{array}{l}\text { adcalc will not be } \\
\text { prepared for all } \\
\text { FSWO-SQA-018, } \\
\text { Safety Level B. }\end{array}$ \\
\hline $\begin{array}{l}\text { 3a. If documentation from ltem } 3 \text { is not avail } \\
\text { required to demonstrate acceptance for } \\
\text { - Explain the need for continued use } \\
\text { - Explain the consequence of not usir } \\
\text { - Describe the risk associated with co } \\
\text { - Describe interior actions taken to mi } \\
\text { - Identify implementation due date. }\end{array}$ & compensatory actions \\
\hline
\end{tabular}

There are no exceptions. All software quality assurance documentation identified in Item 3 is adequately provided and available.

4. Describe adequacy of existing design and user documentation to support software operation/maintenance including necessary user training:

The design and user documentation that are applicable to Radcalc 4.1 are listed in Item 3 . In addition, the Radcalc software integrates a drop-down "help" menu.

Radcalc is designed, codified, tested, documented, and maintained by EnergySolutions for the DOEHQ/EM-63 via a contract through Project Enhancement Corporation (PEC). Both EnergySolutions Document Control and PEC have software quality assurance documentation and backup CDs of the Radcalc 4.1 code and installation files for website use. PEC has the contractual responsibility to maintain all record copy documentation/media for Radcalc 4.1 .

The development of Radcalc 4.1 was in accordance with the requirements identified in QP 3-10, Rev. 9. Industry standard programming techniques appropriate for the software and hardware systems used by Radcalc were used. Software developers incorporated innovations to improve the value of the software to DOE and end users. IEEE recommended standards were used as guides.

EnergySolutions has provided user training as needed to both groups and individuals. EnergySolutions has provided user support for error correction in accordance with QP 3-10.

The contractual requirements for EnergySolutions' involvement with regard to continued support and/or development for Radcalc activities is currently unknown. It is expected that DOE orders and standards shall apply to the extent doing so is contractually required; meets DOE and other customer requirements, priorities, or expectations; and is sufficiently funded. 


\begin{tabular}{|c|c|c|c|}
\hline EXIS IIVG SUR T WARE EVALUAIIUIV KEPURI & \multicolumn{3}{|c|}{ EXISTING SOFTWARE EVALUATION REPORT } \\
\hline \multicolumn{2}{|c|}{ System/Software Name: Radcalc (COTS) } & \multicolumn{2}{|c|}{ Version: 4.1} \\
\hline \multirow{2}{*}{\multicolumn{4}{|c|}{$\begin{array}{l}\text { 5. Describe adequacy of existing test documentation to demonstrate acceptable performance based on } \\
\text { defined software requirements. (Define new test cases required to fully demonstrate performance } \\
\text { and to support regression testing.) } \\
\text { Radcalc } 4.1 \text { was verified and validated (V\&V) in accordance with QP } 3-10, \text { Rev. } 9 \text {. The V\&V } \\
\text { documentation is identified in ltem } 3 \text {, and includes the test plan/procedure and report information. }\end{array}$}} \\
\hline & & & \\
\hline \multicolumn{4}{|c|}{ W Elsting soffware Evaluation Report Reviewlapproval } \\
\hline & & & Approval Date \\
\hline System Engineer & A. V. & & $06 / 05 / 2009$ \\
\hline Independent Technical Reviewer & J. A. & & $06 / 05 / 2009$ \\
\hline System Manager & D. J. & 2 & $06 / 05 / 2009$ \\
\hline Line Manager (Req'd for 3a only) & N/A & & \\
\hline
\end{tabular}

FSWO-059 11/07 